\title{
Characterization of titanium coatings on substrate of Poly (Ether-Ether-Ketone) - PEEK applied through thermal spray process for implant applications
}

\author{
Caracterização de revestimentos de titânio sobre substrato de Poli \\ (Éter- Éter-Cetona) - PEEK, aplicados através do processo de aspersão \\ térmica para aplicações em implantes
}

Antonio Oliveira' ${ }^{1}$, Thais Flores-Sahagun ${ }^{1}$, Ramon Paredes ${ }^{1}$, Andreza Ribeiro ${ }^{1}$, José Athayde ${ }^{1}$, Carlos Siqueira

\begin{abstract}
Samples of PEEK - poly(ether-ether-ketone) were coated with titanium through flame thermal spray process, using nitrogen or argon as carrier gas. The coatings were characterized by optical and scanning electronic microscope (SEM), energy dispersive X-ray detector (EDS) and diffraction x-ray (DRX). Tribological tests were performed on the Titanium ( $\mathrm{Ti}$ ) coatings and an abrasive wear was identified for both samples. The bioactivity of the asprepared coating surface samples was evaluated in in vitro tests by immersion of the samples in simulated body fluid (SBF) for different periods of time, up to 23 days. The coated specimens were analyzed by SEM and EDS and revealed that a layer containing Calcium (Ca) and Phosphorus (P) was deposited upon immersing the samples in SBF, suggesting that compounds similar to bones (apatite) were formed and therefore, the materials have a potential use in implants for consolidating bone fractures.
\end{abstract}

Keywords: Thermal spray process; Titanium coating; PEEK substrate; Bioactivity; Implants; Wear strength.

\section{RESUMO}

Amostras de PEEK - poli (éter-éter-cetona) foram revestidas com titânio através do processo de pulverização térmica por chama utilizando o gás nitrogênio ou argônio como gás de transporte. Os revestimentos foram caracterizados por microscopia óptica electrônica de varredura, espectroscopia de raios $X$ por dispersão em energia (EDS) e difração de raios-X (DRX). Ensaios de tribologia foram realizados sobre os revestimentos de Titânio (Ti) e um desgaste abrasivo foi identificado em ambas as amostras. A bioatividade da superfície de revestimento das amostras preparadas foi avaliada por testes in vitro por imersão das amostras em fluido corporal simulado (SBF) durante diferentes períodos de tempo, até um total de 23 dias. Os revestimentos foram analisados por SEM e EDS após a imersão em SBF, e revelou uma camada contendo Cálcio (Ca) e Fósforo (P) depositado em cima das amostras, o que sugere que compostos similares aos ossos (apatita) foi formado e, por conseguinte, os materiais têm uma potencial utilização em implantes para a consolidação de fraturas ósseas.

Palavras-chave: Processo de pulverização térmica; Revestimentos de Titânio; Amostras de PEEK; Implantes; Resistência ao desgaste. 


\section{INTRODUCTION}

The highlights of this work are the use of flame thermal spray process on a poly(ether-ether-ketone) - PEEK substrate for $\mathrm{Ti}$ coating, the wear tests performed on the materials thus obtained to evaluate its potential use on non-static implants and the in vitro tests results obtained that suggest that the materials are potentially good performance materials for static orthopedic implants.

\section{LITERATURE REVIEW}

Ti-alloys present high compatibility for implant applications but its elastic modulus is much higher than that of bones, causing atrophy in an attempt of the body to protect the bone from the tension generated ${ }^{(1)}$. The strength of legs and arms bones are in the range of $100-200 \mathrm{MPa}$, the strength of the skull is about $97 \mathrm{MPa}$ and that of vertebras are in the range of $1-10 \mathrm{MPa}^{(2)}$. When there is a mismatch in modulus of elasticity between the bone and the implant, implant failure occurs because the stress required by cells adjacent to the implant is shielded and thus, cells do not survive ${ }^{(3)}$. Also, implants are submitted to the action of complex mechanical loadings in salty medium (blood and interstitial fluid) requiring implant materials to have a good corrosion resistance. The $\mathrm{pH}$ of normal blood and interstitial fluid is $7.35-7.45$ but it decreases to about 5.2 in the hard tissue due to implantation and recovers to 7.4 in approximately two weeks. Body fluids contain amino acids and proteins that may accelerate corrosion $^{(4)}$. Therefore, polymers coated with Ti unite the high compatibility of $\mathrm{Ti}$ with the corrosion resistance and elastic modulus of macromolecules and so, these materials are potentially high performance materials for implants applications.

From results obtained by several authors, it was proposed that bone bioactivity of a material could be assessed by examining apatite formation in SBF preliminary to animal experiments ${ }^{(5-9)}$. The SBF solution is supersaturated with respect to calcium phosphate and carbonate, and ion concentration nearly equals to those of human blood plasma without organic components, and so, apatite thus formed is very similar to the bone mineral in its composition and structure ${ }^{(8)}$.

\section{EXPERIMENTAL}

PEEK substrate were grit blasted with alumina mesh size 36 with a CMV equipment followed by powder Ti deposition through flame thermal spray process with a Sultzer equipment and a gun model 6P-II. As a carrier gas, nitrogen (15 SCFH, sample 1) or argon (15 SCFH, sample 2) were used else than $100 \mathrm{SCFH}$ of $\mathrm{O}_{2}$ and $60 \mathrm{SCFH}$ of acetylene. Ti deposition was slow, with cooling $\left(130-138^{\circ} \mathrm{C}\right)$ using compressed air between each pass (24 for sample 1 and 30 for sample 2). The distance gun-substrate varied in the range of $30-50 \mathrm{~cm}$. Sample surfaces were characterized by diffraction X-ray (DRX Empyrian), scanning electronic microscopy (SEM Tescan Vega 3XMU), optical microscopy model
Olympus BX 51M, energy dispersive x-ray detector (EDS Oxford XACT), Rockwell hardness (Versitron Newage Instruments) and tribology (Tribometer CSM). The static partner used in friction with the coated materials was a $100 \mathrm{Cr}_{6}$ sphere, with diameter of $6 \mathrm{~mm}$. The applied force in the tribological tests was of $3 \mathrm{~N}$ in 150.000 cycles $^{(10-11)}$. The evaluation of apatite forming ability was made through in vitro tests and then the formed coating was characterized by EDS. Simulated body fluid (SBF) was prepared by dissolving reagent grade chemicals of $\mathrm{NaCl}, \mathrm{NaHCO}_{3}, \mathrm{KCl}$, $\mathrm{K}_{2} \mathrm{HPO}_{4}, \mathrm{MgCl}_{2} \cdot 6 \mathrm{H}_{2} \mathrm{O}, \mathrm{CaCl}_{2} \cdot 2 \mathrm{H}_{2} \mathrm{O}$, and $\mathrm{Na}_{2} \mathrm{SO}_{4}$ in deionized water and buffered at $\mathrm{pH} 7.4$ with tris-hydroxymethyl aminomethane $\left(\left(\mathrm{CH}_{2} \mathrm{OH}\right)_{3} \mathrm{CNH}_{2}\right)$ and hydrochloric acid $(1 \mathrm{~mol} / \mathrm{L})$ at $36,5 \pm 0.5^{\circ} \mathrm{C}$ according to ISO / FDIS 23317. Samples were soaked in $15 \mathrm{~mL}$ of SBF (filtered through a $0,45 \mu \mathrm{m}$ membrane (Sartorius ${ }^{\circledR}$, Spain) in a Falcon tube and stored in a water bath at $37^{\circ} \mathrm{C}\left( \pm 1^{\circ} \mathrm{C}\right)$ up to 23 days. After immersion for a pre-determined period of time $(9,18$ or 23 days), the samples were removed from the SBF, gently rinsed with deionized water and then dried in ambient temperature. The samples were stored in a desiccator.

\section{RESULTS AND DISCUSSION}

Figures 1(A) and 1(B) and Figures 2(A) and 2(B) present optical images of the Ti coated PEEK when nitrogen (sample 1) or argon (sample 2), respectively, was used as the carrier gas in the flame thermal spray process. It can be seen visually that samples 1 and 2 presented a yellowish colour because of the formation of TiN that has a golden colour. The coating layer in sample 2 was in the range of 214-304 $\mu \mathrm{m}$, thicker than the one of sample 1 because instead of 30 passes, sample 1 was submitted to 24 passes in the flame

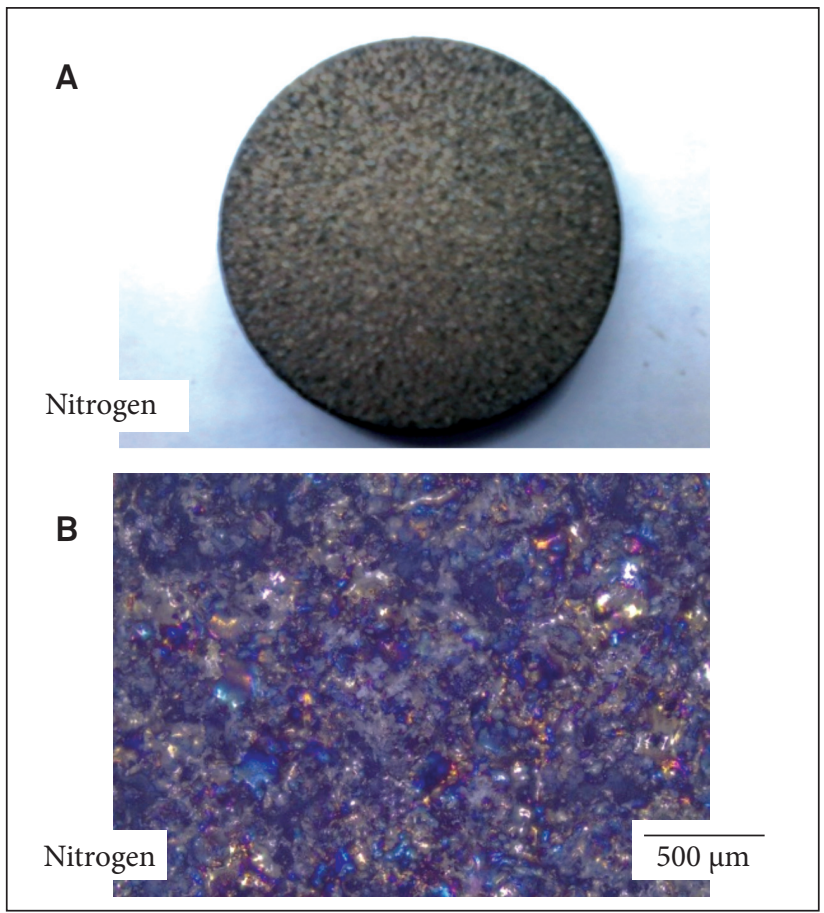

Figure 1: Sample 1 optical microscope (Ti coating on PEEK). 
thermal spray process. Hardness of the Ti coatings were of 24.7 RHA and 20.0 RHA for samples 1 and 2, respectively.

Figures 3 and 4 show the diffraction patterns of both samples and the compounds identified. DRX results showed that in both samples osbornite (TiN), hongquilite (Ti) and titanium (Ti) were found. Aluminium was used as the sample uphold.

Figures 5(A) and 5(C) show that the formation of worn tracks characteristic of the abrasive wear, with grooves coincidental to the movement direction were formed. It was also observed the occurrence of the same abrasive wear in the static partners (spheres) as Figures 5(B) and 5(D) shows.

The coefficient of friction of the Ti coating of samples 1 and 2 presented an average value of 0.75 and 0.60 respectively as shown in Fig. 6. TiN presents a friction coefficient of 0.65 . The wear tests show that after 120.000 cycles on sample 2 , there is a tendency to

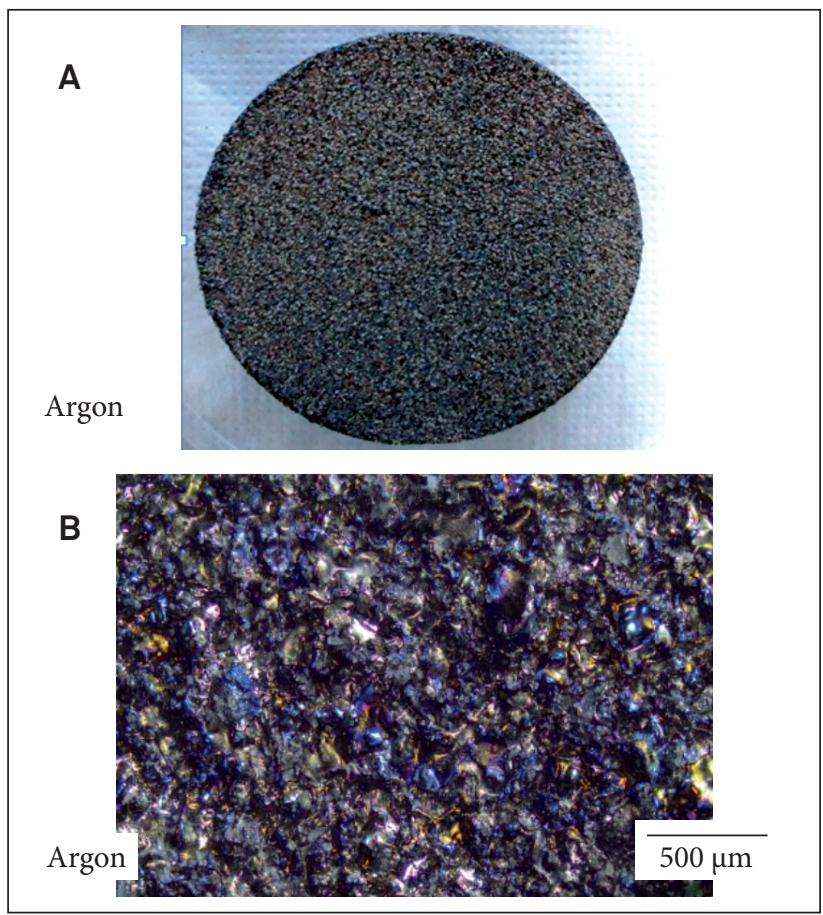

Figure 2: Sample 2 optical microscope (Ti coating on PEEK).

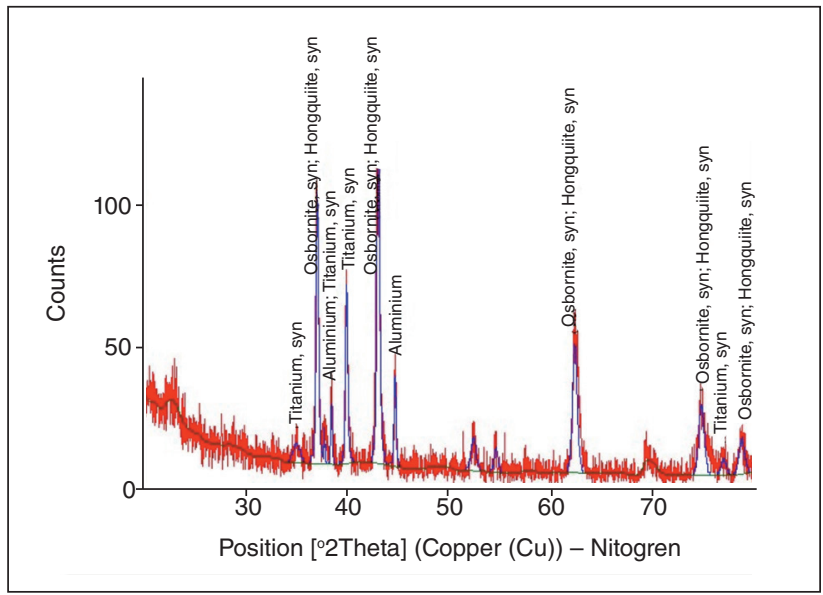

Figure 3: DRX of sample 1.

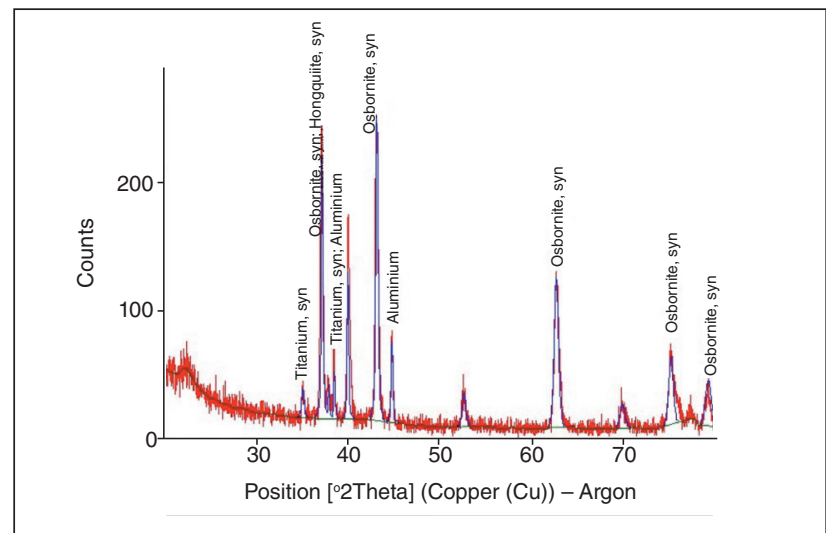

Figure 4: DRX of sample 2.

A

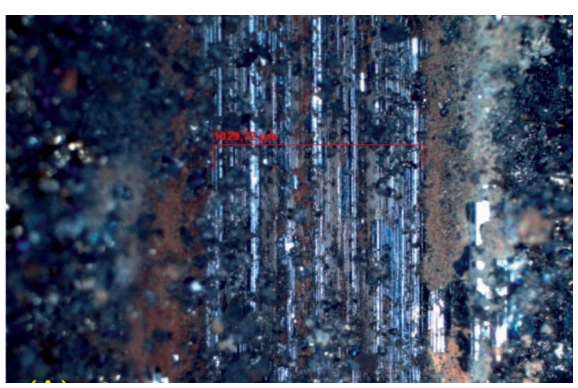

B

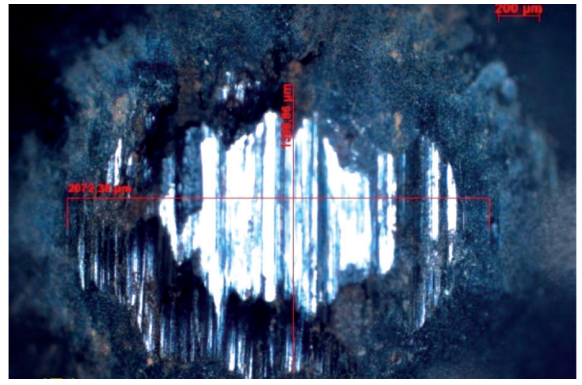

C

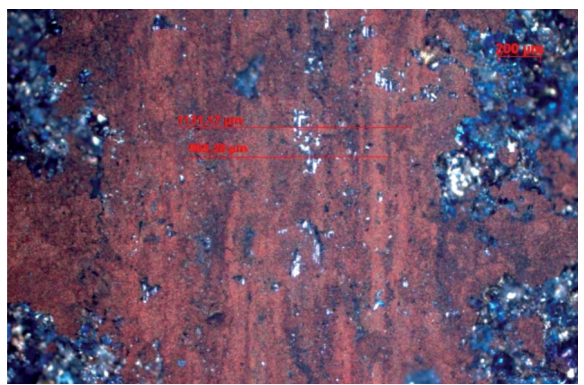

D

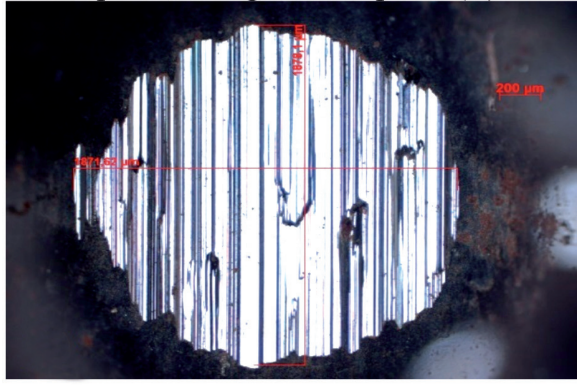

Figure 5: Images of wear tests. Track, nitrogen atmosphere $(A)$ Sphere, nitrogen atmosphere (B); Track, argon atmosphere (C); Sphere, argon atmosphere (D). 
the stabilization while after 40.000 cycles a stabilization is already registered for sample 1 that also presents high dispersion of values (extremes of 0.55 and 0.90 ).

Both curves show an evolution of the coefficient of friction in relation to the number of cycles. Sample 1, obtained using nitrogen as a carrier gas in the thermal spray process presented higher values of coefficient of friction than sample 2. This result may indicate that sample 1 presented a higher TiN content than sample 2 as this compound is very hard (Rockwell C hardness of 85). For both samples, a lot amount of material in the form of particles was obtained along and externally to the wear tracks. Also, optical microscopy showed that with the number of cycles tested (150.000), none of the Ti coating on the PEEK substrate fractured. Figure 7 present particles obtained in sample 1 and 2 wear test and they may be characterized morphologically according to ASTM F 1877 - 05 Standard Practice for Characterization of Particles as shown in Figure X2.6 - granular, irregular-rough and to Figure X2.5 - Granular, irregular-smooth, respectively ${ }^{(12)}$.

Based on the images of particles obtained in the wear tests, it can be inferred that particles with dimension higher than $50 \mu \mathrm{m}$ are probably derived from the thermal spray process and were removed during the test. On the other hand, particles with dimension lower than $5 \mu \mathrm{m}$ may have been generated by the mechanical action of wear.

The hydroxyapatite formation in the surface of samples during immersion in the SBF was investigated by SEM and EDS. No alkaline treatment was performed on the samples trying to avoid a possible inflammatory reaction when used in vivo, which could be exacerbated by the release of sodium ions ${ }^{(13)}$. The beginning of the formation of the hydroxyapatite compound was observed after 18 days of immersion in SBF. The morphological appearance of the coating was observed by SEM.

SEM images of the PEEK sample coated with titanium using nitrogen as carrier gas (sample 1) followed by immersion in the $\mathrm{SBF}$ at $37^{\circ} \mathrm{C}\left( \pm 1^{\circ} \mathrm{C}\right)$ for 23 days. SEM image showed a darker side of the micrograph corresponding to the coating formed in the in vitro tests and the lighter side of the micrograph corresponding to the titanium coating. It is believed that the apatite nuclei were formed after approximately 18 days of immersion and

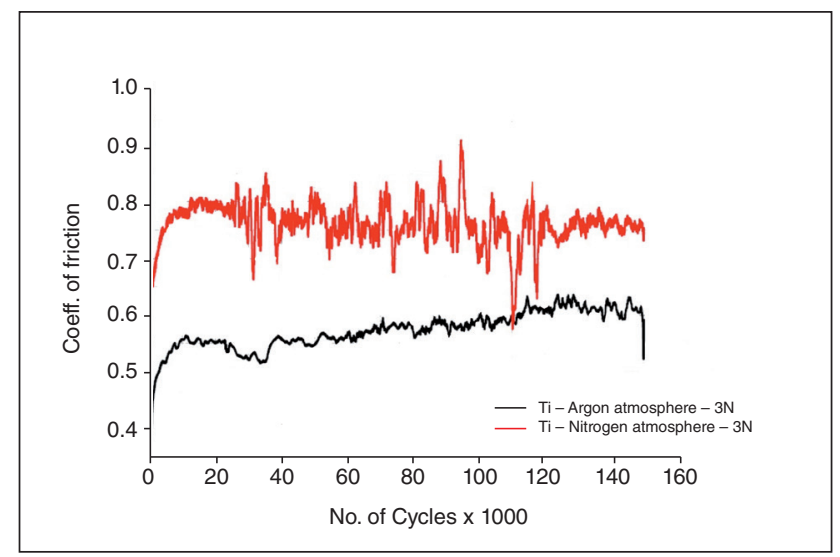

Figure 6: Coefficient of friction of samples 1 and 2.

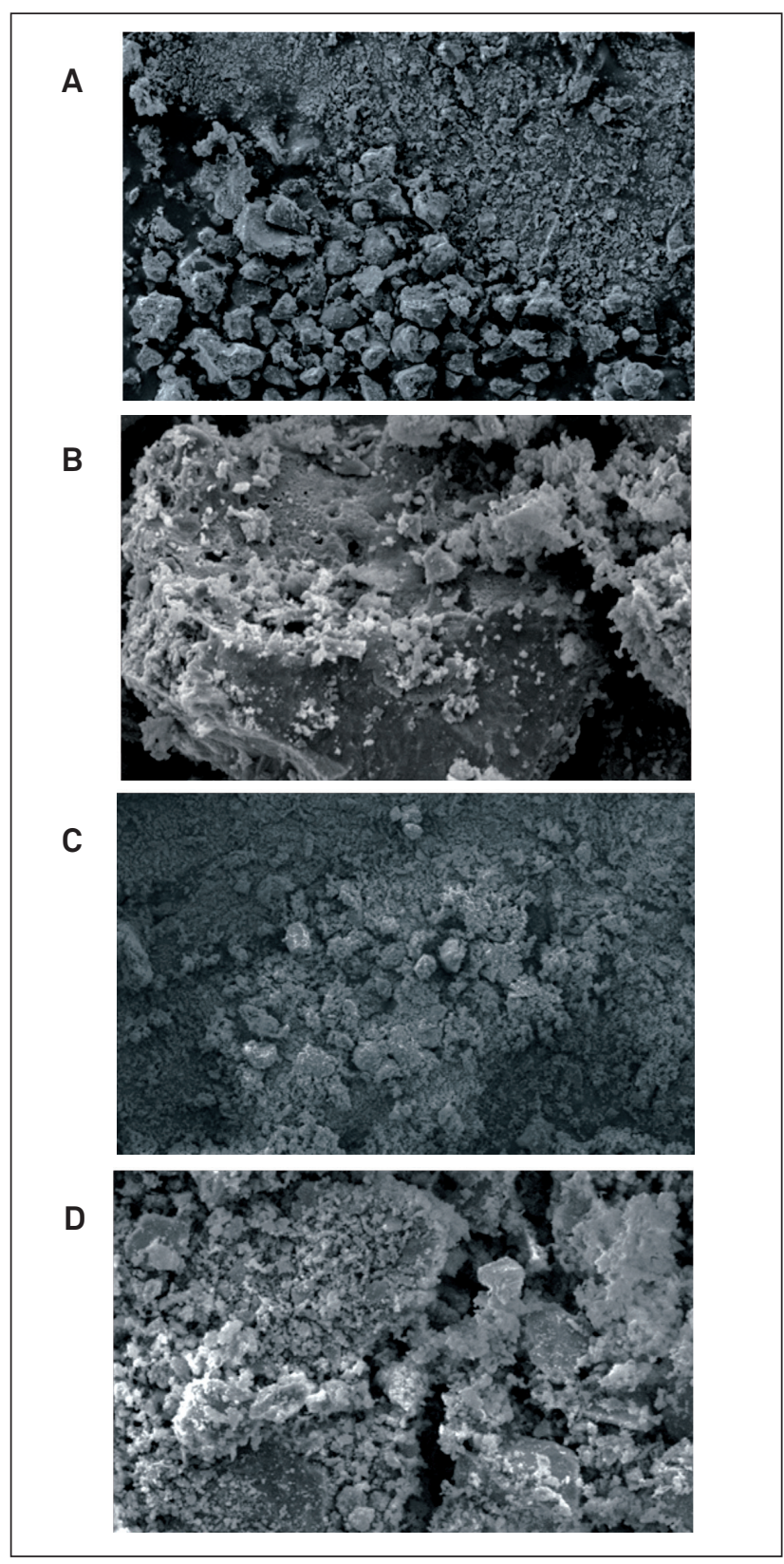

Figure 7: SEM of particles of wear tests of samples 1 and 2 nitrogen atmosphere $(\mathrm{A}-100 \mu \mathrm{m}$, and $\mathrm{B}, 10 \mu \mathrm{m})$ - argon atmosphere (C$100 \mu \mathrm{m}$, and $\mathrm{D}, 10 \mu \mathrm{m})$.

continued to grow, spreading over the entire analyzed surface. EDS detected the presence of $\mathrm{Ca}$ and $\mathrm{P}$ in the coating surface of the samples and the relation $\mathrm{Ca} / \mathrm{P}$ of the compounds found were to be 1.02 , consistent to the formation of $\mathrm{CaHPO}_{4}, \mathrm{Ca}_{2} \mathrm{P}_{2} \mathrm{O}_{7}$, $\mathrm{Ca}_{2} \mathrm{P}_{2} \mathrm{O}_{7} \cdot 2 \mathrm{H}_{2} \mathrm{O}$ or $\left.\mathrm{CaHPO}_{4} \cdot 2 \mathrm{H}_{2} \mathrm{O}\right), 0.47$, consistent to the formation of $\mathrm{Ca}\left(\mathrm{H}_{2} \mathrm{PO}_{4}\right) 2 . \mathrm{H}_{2} \mathrm{O}$ and 1.7 , consistent to the formation of hydroxyapatite $-\mathrm{Ca}_{10}\left(\mathrm{PO}_{4}\right)_{6}(\mathrm{OH})_{2}{ }^{(14)}$.

\section{CONCLUSIONS}

It was possible to prepare good Ti coatings on PEEK substrate using flame thermal spray process and when argon was used as a 
carrier gas, the formation of TiN was lower than when nitrogen was used as a carrier gas and thus, the coating presented a lower coefficient of friction. Although in wear tests a significant amount of particles were generated for both samples, none of the coatings was fractured within 150.000 cycles. The formation of hydroxyapatite and other precursors were detected by EDS on samples 1 and 2 after the in vitro tests. It can be concluded that PEEK coated by Ti may be potentially used as static orthopedic implants because the materials present bioactivity and when not submitted to wear, the coatings seem stable.

\section{ACKNOWLEDGMENTS}

The authors wish to thank the National Council for Scientific and Technological Research (CNPq, process 310064/2011-2) for the fellowship given.

\section{FUNDING}

The authors wish to thank the National Council for Scientific and Technological Research (CNPq, process 446263/2014-1) for the financial support given.

\section{REFERENCES}

1. Strazar, K., A. Cör and V. Antolic (2006). "Biological impact of polyacetal particles on loosening of isoelastic stems." Biomacromolecules 7(9): 2507-2511.

2. Teoh, S. (2000). "Fatigue of biomaterials: a review." International Journal of Fatigue 22(10): 825-837.
3. Abdel-Hady Gepreel, M. and M. Niinomi (2013). "Biocompatibility of Ti-alloys for long-term implantation." Journal of the Mechanical Behavior of Biomedical Materials 20(0): 407-415.

4. Hanawa, T. (1999). "In vivo metallic biomaterials and surface modification." Materials Science and Engineering: A 267(2): 260-266.

5. Kokubo, T., H. Kushitani, S. Sakka, T. Kitsugi and T. Yamamuro (1990). "Solutions able to reproduce in vivo surface-structure changes in bioactive glass-ceramic A-W." J Biomed Mater Res 24(6): 721-734.

6. Takadama, H., M. Hashimoto, M. Mizuno and T. Kokubo (2004) "Round-robin test of SBF for in vitro measurement of apatiteforming ability of synthetic materials." Phosphorus Research Bulletin 17(0): 119-125.

7. Lu, X. and Y. Leng (2005). "Theoretical analysis of calcium phosphate precipitation in simulated body fluid." Biomaterials 26(10): 1097-1108.

8. Kokubo, T. and H. Takadama (2006). "How useful is SBF in predicting in vivo bone bioactivity?" Biomaterials 27(15): 2907-2915.

9. Müller, L. and F. A. Müller (2006). "Preparation of SBF with different content and its influence on the composition of biomimetic apatites." Acta Biomaterialia 2(2): 181-189.

10. Zum Gahr, K.-H. (1987). Microstructure and wear of materials, Elsevier.

11. Michael, P., E. Rabinowicz and Y. Iwasa (1991). "Friction and wear of polymeric materials at 293, 77 and 4.2 K." Cryogenics 31(8): 695-704.

12. ASTM F 1877 - 05 Standard Practice for Characterization of Particles.

13. Jonasova, L., F. A. Müller, A. Helebrant, J. Strnad and P. Greil (2002) "Hydroxyapatite formation on alkali-treated titanium with different content of $\mathrm{Na}+$ in the surface layer." Biomaterials 23(15): 3095-3101.

14. de Almeida Filho, E., C. M. de Assis, L. de OVercik and A. C Guastaldi (2007). "Biomateriais: deposição de hidroxiapatita sobre superfície de Ti-CP modificada por aspersão térmica." Química Nova 30(5): 1229. 